\title{
EVALUATION ON SUMBER SENENG NATURAL PARK, REMBANG AS TOURISM OBJECT USING ADO-ODTWA ANALYSIS
}

\author{
Anityas Dian Susanti *), Mutiawati Mandaka
}

*) Corresponding author email : tyas@unpand.ac.id

Program Studi S1 Teknik Arsitektur, Fakultas Teknik, Universitas Pandanaran, Semarang - Indonesia

\author{
Article info \\ MODUL vol 19 no 1 , issues period 2019 \\ Doi $\quad: 10.14710 / \mathrm{mdl} .19 .1 .2019 .25-32$ \\ Received : 25th march 2019 \\ Revised : : 17th may 2019 \\ Accepted : 22nd may 2019
}

\section{Abstract}

Tourism has proven as economic generator in several local districts in Indonesia. Natural resources have significant factors in accelerating the tourism developments. Sumber seneng in Rembang county is an example of the natural resource based tourism district. However the development of Sumber seneng park is still on going process related to the district potential's study. ADO-ODTWA (Analisis Daerah Operasi Obyek dan Daya Tarik Wisata Alam) is an analysis for tourist attraction from Indonesia Forest and Natural Conservation Agency. This research was part of the study to evaluate Sumber seneng park as object tourism case using ADO-ODTWA analysis. This study performed literature study to arrange the evaluation sheet, site observation based on evaluation's results as case study. The result of this study shown detail steps to evaluate tourism object and mentioned that Sumber Seneng Natural Park has potentials to be tourism object and need more development to optimize it.

Keywords: tourism;natural park; potential; evaluation; ADO-ODTWA; Sumber seneng; Rembang

\section{PENDAHULUAN}

Sektor kepariwisataan hingga kini masih dipandang sebagai salah satu unsur penggerak perekonomian yang mampu meningkatkan kesejahteraan. Banyak faktor yang mendorong terjadinya pergerakan untuk melakukan perjalanan wisata. Sebagai akibatnya akan muncul mata rantai yang saling mengkait sehingga tidak salah bila pariwisata dipandang sebagai sebuah industri. Aktivitas yang muncul dari pariwisata diyakini mampu mendorong percepatan dan pemulihan ekonomi.

Anityas Dian Susanti, Mutiawati Mandaka
Pariwisata yang berkembang akan berujung pada peningkatan penghasilan daerah dan taraf hidup masyarakat. Untuk memenuhi kebutuhan rekreasi perlu ditunjang dengan adanya daya tarik wisata. Dipihak lain, maju mundurnya pariwisata sebuah daerah sangat dipengaruhi komitmen dan konsistensi daerah dalam mengelola potensi wisata secara total. Menurut Undangundang No. 5 tahun 1990 tentang Konservasi Sumberdaya Alam Hayati dan Ekosistemnya, Taman Wisata Alam adalah kawasan pelestarian alam yang terutama dimanfaatkan untuk pariwisata dan rekreasi alam.

Penilaian potensi Taman Wisata Alam Sumber Semen menggunakan pedoman Analisis Daerah Operasi Obyek dan Daya Tarik Wisata Alam (ADO-ODTWA) Direktorat Jenderal Perlindungan Hutan dan Konservasi Alam tahun 2003 untuk mengetahui kondisi dan menentukan skala prioritas pengembangan kawasan TWA. Kriteria yang dipakai sebagai dasar penilaian potensi kawasan TWA meliputi: daya tarik obyek wisata darat, potensi pasar, kadar hubungan/aksesibilitas, kondisi sekitar kawasan, pengelolaan dan pelayanan, iklim, akomodasi, sarana dan prasarana penunjang, ketersediaan air bersih, hubungan dengan obyek wisata di sekitarnya, keamanan, daya dukung kawasan, pengaturan pengunjung, pemasaran, dan pangsa pasar. Analisis data menggunakan Pedoman Analisis Daerah Operasi Obyek dan Daya Tarik Wisata Alam Dirjen PHKA 2003 [1]. Komponen yang dinilai yaitu (1) Daya tarik objek wisata; (2) Aksesibilitas; (3) Kondisi lingkungan sosial ekonomi; (4) Akomodasi; (5) Sarana dan prasarana penunjang; (6) Ketersedian air bersih; (7) Keamanan; dan (8) Kenyamanan

\section{METODE}

Penelitian dilakukan di kawasan Sumber Seneng, Rembang pada tahun adalah studi literatur untuk menghasilkan daftar evaluasi; observasi lapangan untuk menilai objek dengan daftar evaluasi tadi; 
pengakumulasian hasil yang dimaknai dengan klas tingkatan hasil studi literature secara studi kasus.

Data dalam penelitian ini berupa Data primer yang merupakan hasil pengamatan di lapangan dan wawancara responden. Pengambilan sampel pada responden disesuaikan dengan tujuan penelitian; dan data sekunder meliputi literatur pendukung maupun dokementasi tambahan .

Metode pembahasan secara terstruktur meliputi :

1. Evaluasi obyek Sumber Seneng berdasarkan pedoman Analisis Daerah Operasi - Obyek dan Daya Tarik Wisata Alam yang ditetapkan Direktorat Jenderal Perlindungan Hutan dan Konservasi Alam (Dirjen PHKA) tahun 2003.

Kriteria yang dipakai sebagai dasar penilaian meliputi: daya tarik obyek wisata darat, potensi pasar, kadar hubungan/aksesibilitas, kondisi sekitar kawasan, pengelolaan dan pelayanan, iklim, akomodasi, sarana dan prasarana penunjang, ketersediaan air bersih, hubungan dengan obyek wisata di sekitarnya, keamanan, daya dukung kawasan, pengaturan pengunjung, pemasaran, dan pangsa pasar.

2. Pembagian klas berdasarkan penilaian dan pembobotan yang diperoleh tiap-tiap kriteria.

Kelas hasil penilaian terbagi menjadi tiga (rendah, sedang, tinggi), sedangkan pembobotan bervariasi dari 1 hingga 6

\section{ANALISA DAN PEMBAHASAN}

Analisis Daerah Operasi - Obyek dan Daya Tarik Wisata Alam merupakan suatu kegiatan analisis terhadap suatu obyek wisata alam dengan menggunakan instrumen kriteria penilaian dan pengembangan untuk mendapatkan penilaian dapat atau tidaknya suatu obyek dikembangkan menjadi obyek wisata.

Hasil rekapitulasi penilaian dapat mengindikasikan unsur-unsur dan sub unsur yang tidak mendapat nilai maksimal dan perlu ditingkatkan, meskipun lokasi daya tarik wisata yang bersangkutan memperoleh nilai tertinggi di antara lokasi-lokasi daya tarik wisata lainnya yang dinilai secara bersamaan, sehingga akan diperoleh rekomendasi berupa upaya-upaya yang harus dilakukan dalam pengelolaan obyek dan daya tarik wisata selanjutnya. Berikut ini evaluasi dari objek wisata Sumber Seneng terhadap kriteria Penilaian Daya Tarik Obyek Wisata Berdasarkan Pedoman ADO-ODTWA Dirjen PHKA tahun 2003.

Sumber seneng memiiki potensi andalan berupa sumber daya air (lihat gambar 1). Potensi alam di Sumber seneng dan fasilitas yang belum optimal memerlukan kajian lebih lanjut untuk perbaikan maupun pengembangan (lihat gambar 2 dan 3 ).

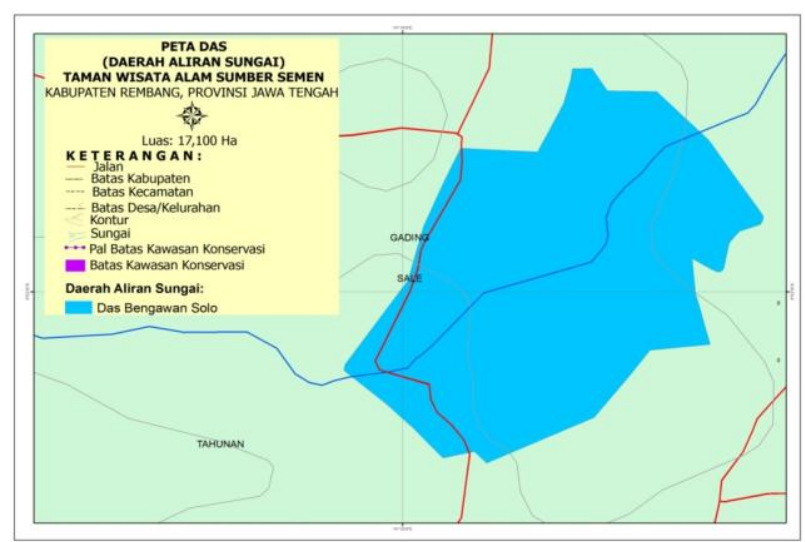

Gambar 1. Peta Daerah Aliran Sungai Sumber Seneng, Rembang

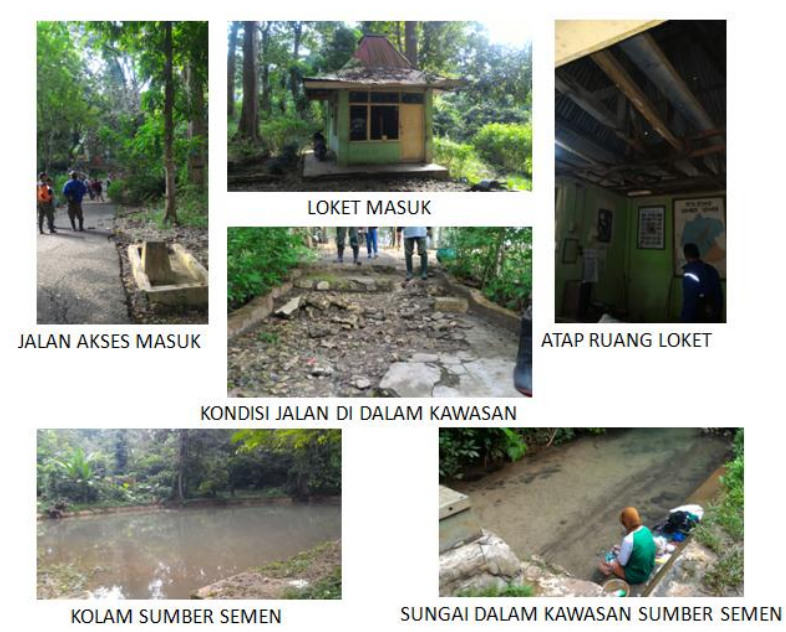

Gambar 2. Kondisi Alam di Sumber Seneng

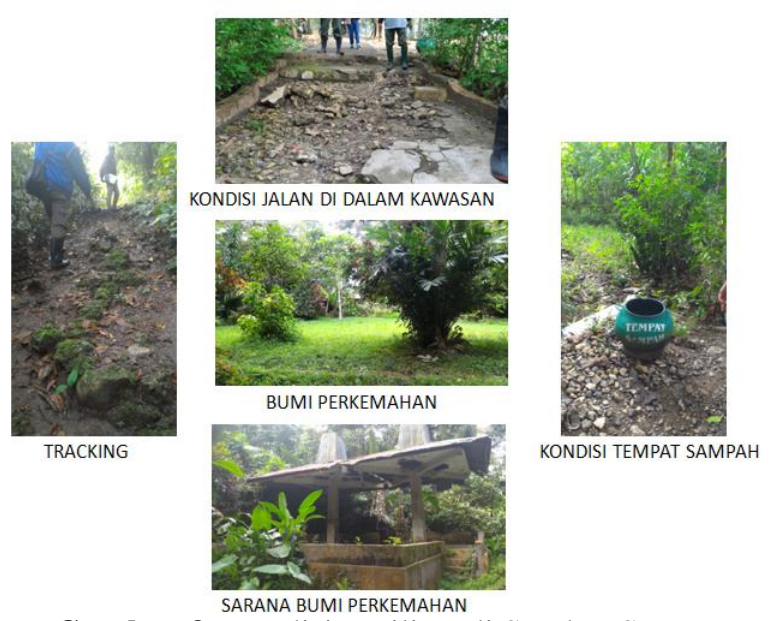

Gambar 3. Kondisi Fasilitas di Sumber Seneng

Pada tabel 1 dapat diketahui bahwa Sumber Seneng memiliki 4 unsur daya tarik objek wisata berupa : pandangan lepas di dalam obyek, variasi pandangan di dalam obyek, pandangan lepas menuju obyek, 
keserasian warna dan bangunan dalam obyek, pandangan/kondisi lingkungan obyek sehingga mendapat nilai $25 ; .4$ keunikan sumber daya berupa Sumber air panas, Gua, Air terjun, Flora fauna, Adat istiadat / budaya; semua (5) sumber daya alam : Batuan,. Flora, Fauna, Air,. Gejala alam;

Tabel 1 Penilaian Daya Tarik Objek Wisata (Bobot 6)

\begin{tabular}{|c|c|c|c|c|c|c|}
\hline NO & UNSUR/SUB UNSUR & & & NILA & & \\
\hline \multirow[t]{2}{*}{1.} & Keindahan alam: & $\begin{array}{l}\text { Ada } \\
5\end{array}$ & $\begin{array}{l}\text { Ada } \\
4\end{array}$ & $\begin{array}{l}\text { Ada } \\
3\end{array}$ & $\begin{array}{l}\text { Ada } \\
2\end{array}$ & Ada 1 \\
\hline & 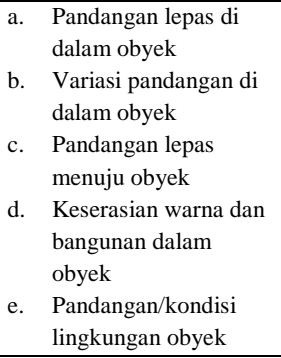 & 30 & $\underline{25}$ & 20 & 15 & 10 \\
\hline \multirow[t]{2}{*}{2.} & $\begin{array}{l}\text { Keunikan sumber daya } \\
\text { alam: }\end{array}$ & $\begin{array}{l}\text { Ada } \\
5 \\
\end{array}$ & $\begin{array}{l}\text { Ada } \\
4 \\
\end{array}$ & $\begin{array}{l}\text { Ada } \\
3 \\
\end{array}$ & $\begin{array}{l}\text { Ada } \\
2 \\
\end{array}$ & Ada 1 \\
\hline & $\begin{array}{l}\text { a. Sumber air panas } \\
\text { b. Gua } \\
\text { c. Air terjun } \\
\text { d. Flora fauna } \\
\text { e. Adat istiadat / budaya }\end{array}$ & 30 & 25 & 20 & $\underline{15}$ & 10 \\
\hline \multirow[t]{2}{*}{3.} & $\begin{array}{l}\text { Banyaknya jenis sumber } \\
\text { daya alam yang } \\
\text { menonjol: }\end{array}$ & $\begin{array}{l}\text { Ada } \\
5\end{array}$ & $\begin{array}{l}\text { Ada } \\
4\end{array}$ & $\begin{array}{l}\text { Ada } \\
3\end{array}$ & $\begin{array}{l}\text { Ada } \\
2\end{array}$ & Ada 1 \\
\hline & $\begin{array}{l}\text { a. Batuan } \\
\text { b. Flora } \\
\text { c. Fauna } \\
\text { d. Air } \\
\text { e. Gejala alam }\end{array}$ & $\underline{\mathbf{3 0}}$ & 25 & 20 & 15 & 10 \\
\hline \multirow[t]{2}{*}{4.} & $\begin{array}{l}\text { Keutuhan sumber daya } \\
\text { alam: }\end{array}$ & $\begin{array}{l}\text { Ada } \\
4 \\
\end{array}$ & $\begin{array}{l}\text { Ada } \\
3 \\
\end{array}$ & $\begin{array}{l}\text { Ada } \\
2 \\
\end{array}$ & $\begin{array}{l}\text { Ada } \\
1 \\
\end{array}$ & $\begin{array}{l}\text { Tidak } \\
\text { Ada }\end{array}$ \\
\hline & $\begin{array}{l}\text { a. Batuan } \\
\text { b. Flora } \\
\text { c. Fauna } \\
\text { d. Ekosistem }\end{array}$ & $\underline{\mathbf{3 0}}$ & 25 & 20 & 15 & 10 \\
\hline \multirow[t]{2}{*}{5.} & $\begin{array}{l}\text { Kepekaan sumber daya } \\
\text { alam: }\end{array}$ & $\begin{array}{l}\text { Ada } \\
5 \\
\end{array}$ & $\begin{array}{l}\text { Ada } \\
4 \\
\end{array}$ & $\begin{array}{l}\text { Ada } \\
3 \\
\end{array}$ & $\begin{array}{l}\text { Ada } \\
2 \\
\end{array}$ & Ada 1 \\
\hline & $\begin{array}{l}\text { a. Geologi/Batuan } \\
\text { b. Flora } \\
\text { c. Fauna } \\
\text { d. Erosi } \\
\text { e. Ekosistem }\end{array}$ & $\underline{\mathbf{3 0}}$ & 25 & 20 & 15 & 10 \\
\hline \multirow[t]{2}{*}{6.} & $\begin{array}{l}\text { Jenis kegiatan/aktivitas } \\
\text { wisata alam: }\end{array}$ & $>7$ & $6-7$ & $4-5$ & $2-3$ & Ada 1 \\
\hline & $\begin{array}{l}\text { a. Tracking } \\
\text { b. Mendaki } \\
\text { c. Rafting } \\
\text { d. Camping } \\
\text { e. Pendidikan } \\
\text { f. Religius } \\
\text { g. Hiking } \\
\text { h. Canoing } \\
\text { i. Memancing }\end{array}$ & 30 & $\underline{25}$ & 20 & 15 & 10 \\
\hline \multirow[t]{2}{*}{7.} & $\begin{array}{l}\text { Kebersihan lokasi (tidak } \\
\text { ada pengaruh) dari: }\end{array}$ & $\mathbf{0}$ & $1-2$ & $3-4$ & $5-6$ & Ada 7 \\
\hline & $\begin{array}{l}\text { a. Alam } \\
\text { b. Industri } \\
\text { c. Jalan ramai (kebisingan }\end{array}$ & 30 & $\underline{25}$ & 20 & 15 & 10 \\
\hline
\end{tabular}

\begin{tabular}{|c|c|c|c|c|c|c|}
\hline & $\begin{array}{l}\text { kendaraan bermotor) } \\
\text { d. Pemukiman penduduk } \\
\text { e. Sampah } \\
\text { f. Binatang (pengganggu) } \\
\text { g. Corat-coret } \\
\text { (vandalisme) }\end{array}$ & & & & & \\
\hline \multirow[t]{2}{*}{8.} & Keamanan kawasan: & $\begin{array}{l}\text { Ada } \\
5 \\
\end{array}$ & $\begin{array}{l}\text { Ada } \\
4\end{array}$ & $\begin{array}{l}\text { Ada } \\
\mathbf{3} \\
\end{array}$ & $\begin{array}{l}\text { Ada } \\
2 \\
\end{array}$ & Ada 1 \\
\hline & $\begin{array}{l}\text { a. Penebangan liar dan } \\
\text { perambahan } \\
\text { b. Kebakaran } \\
\text { c. Gangguan terhadap } \\
\text { flora / fauna } \\
\text { d. Masuknya flora } \\
\text { e. Eksotik }\end{array}$ & 30 & $\underline{25}$ & 20 & 15 & 10 \\
\hline & Nilai & 1230 & & & & \\
\hline
\end{tabular}

Pada tabel 2 dapat diketahui bahwa Sumber Seneng memiliki 2 potensi pasar (bobot 5) berupa : potensi demografi dan potensi kebutuhan parwisata. Sehingga untuk potensi demografi yang memiliki lebih dari 20000 penduduk dengan tingkat kepadatan sekitar 500-600 mendapatkan nilai 140 . Potensi kebutuhan wisata yang terdiri dari : tingkat pendapatan Jawa Tengah yang cukup tinggi, kesejahteraan baik, kepadatan cukup tinggi dan memiliki kesempatan (4unsur terpenuhi) sehingga mendapat nilai 25 . Total nilai pada potensi pasar TWA SUmberSeneng memperoleh 165 poin dengan bobot 5 sehingga nilai akumulatifnya adalah 825 .

Tabel 2 Penilaian Potensi Pasar (Bobot 5)

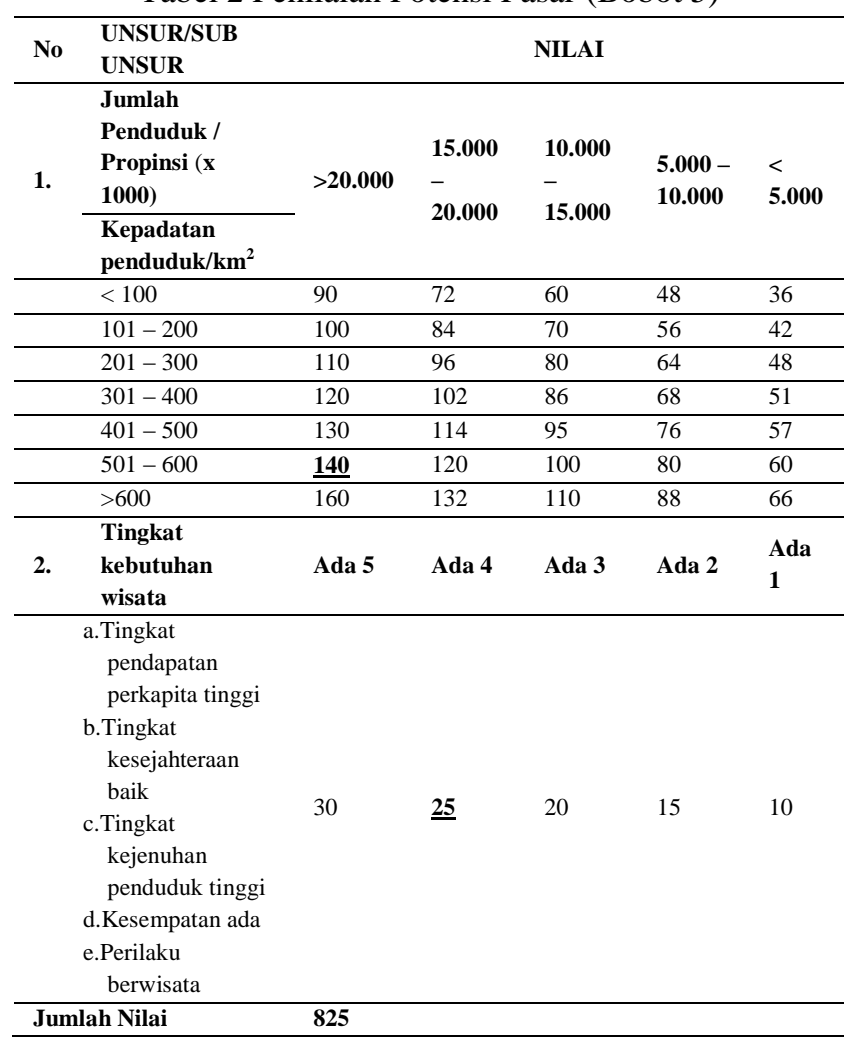

Pada tabel 3 dapat diketahui bahwa Sumber Seneng memiliki 4 potensi aksesibilitas (bobot 5) berupa : Jarak 
dari Semarang diantara 76-150km (60poin), jarak dengan bandara internasional Jakarta lebih dari $600 \mathrm{~km}$ (20poin), waktu tempuh menuju Semarang sekitar 34 jam (20 poin) dan frekuensi kendaraan umum kurang dari 19 buahpari (10poin) . Total nilai pada potensi pasar TWA SUmberSeneng memperoleh 110 poin dengan bobot 5 sehingga nilai akumulatifnya adalah 550 .

Tabel 3 Penilaian Kadar Hubungan/Aksesibilitas (Bobot 5)

\begin{tabular}{|c|c|c|c|c|c|c|}
\hline \multirow{2}{*}{ NO } & \multirow{2}{*}{$\begin{array}{l}\text { UNSUR/SUB UNSUR } \\
\text { Kondisi jalan darat dari } \\
\text { ibukota propinsi }\end{array}$} & \multicolumn{5}{|c|}{ NILAI } \\
\hline & & Baik & Cukup & & Sedang & Buruk \\
\hline & $<75$ kilometer & 80 & 60 & 4 & & 20 \\
\hline & $76-150$ kilometer & $\underline{60}$ & 40 & 2 & & 15 \\
\hline & $151-225$ kilometer & 40 & 20 & 1 & & 5 \\
\hline & $>225$ kilometer & 20 & 10 & 5 & & 1 \\
\hline \multirow{6}{*}{2.} & & \multicolumn{5}{|c|}{ Jarak dalam Km } \\
\hline & internasional/domestik & $\begin{array}{l}s / d \\
150\end{array}$ & $\begin{array}{l}\text { 151- } \\
300\end{array}$ & $\begin{array}{l}301- \\
450\end{array}$ & $\begin{array}{l}451- \\
600\end{array}$ & $>600$ \\
\hline & $\begin{array}{l}\text { Jayapura/ Pekanbaru/ } \\
\text { Ambon/ Kupang }\end{array}$ & 15 & 20 & 5 & 1 & - \\
\hline & Medan/ Manado & 25 & 20 & 15 & 10 & 5 \\
\hline & Denpasar & 30 & 25 & 20 & 15 & 10 \\
\hline & Jakarta & 40 & 35 & 30 & 25 & $\underline{\underline{20}}$ \\
\hline \multirow{3}{*}{3.} & Waktu tempuh dari & \multicolumn{5}{|c|}{ Waktu tempuh (dalam jam) } \\
\hline & ibukota propinsi & $1-2$ & $2-3$ & $3-4$ & $4-5$ & $>5$ \\
\hline & & 30 & 25 & $\underline{20}$ & 15 & 10 \\
\hline \multirow[t]{2}{*}{4.} & $\begin{array}{l}\text { Frekuensi kendaraan } \\
\text { umum dari pusat } \\
\text { informasi ke obyek } \\
\text { (buah/hari) }\end{array}$ & $>50$ & $40-49$ & $\begin{array}{l}30- \\
39\end{array}$ & $20-29$ & $<19$ \\
\hline & & 30 & 25 & 20 & 15 & $\underline{10}$ \\
\hline Jum & h Nilai & 550 & & & & \\
\hline
\end{tabular}

Pada tabel 4 dapat diketahui bahwa Sumber Seneng memiliki sedang dalam penyusunan tata ruang (15), memiliki tingkat pengangguran $13 \%$ (25), mata pencaharian utama penduduknya adalah petani (20),dengan pendidikan mayoritas SLTP, ruang gerak pengunjungnya kurang dari 30 ha (10), dengan tanah subur (20) sehingga potensial (20) dan penduduknya mendukung kegiatan wisata (30) sehingga nilai totalnya 825

Tabel 4 Penilaian Kondisi Sekitar Kawasan (Bobot 5)

\begin{tabular}{|c|c|c|c|c|c|}
\hline NO & $\begin{array}{l}\text { UNSUR } \\
\text { /SUB UNSUR }\end{array}$ & & & AII & \\
\hline \multirow[t]{2}{*}{1} & $\begin{array}{l}\text { Tata ruang } \\
\text { wilayah } \\
\text { obyek }\end{array}$ & $\begin{array}{l}\text { Ada dan } \\
\text { sesuai }\end{array}$ & $\begin{array}{l}\text { Ada tapi } \\
\text { tidak } \\
\text { sesuai }\end{array}$ & $\begin{array}{l}\text { Dalam } \\
\text { proses } \\
\text { penyusuna } \\
n\end{array}$ & Tidak ada \\
\hline & & 30 & 20 & $\underline{15}$ & 5 \\
\hline \multirow[t]{2}{*}{2} & $\begin{array}{l}\text { Tingkat } \\
\text { penganggura } \\
\mathrm{n}\end{array}$ & $>15 \%$ & $10-15 \%$ & $5-9 \%$ & $<5 \%$ \\
\hline & & 30 & $\underline{25}$ & 20 & 15 \\
\hline 3 & $\begin{array}{l}\text { Mata } \\
\text { pencaharian } \\
\text { penduduk }\end{array}$ & $\begin{array}{l}\text { Sebagian } \\
\text { besar } \\
\text { buruh }\end{array}$ & $\begin{array}{l}\text { Sebagian } \\
\text { besar } \\
\text { pedagang } \\
\text { dan } \\
\text { pengrajin }\end{array}$ & $\begin{array}{l}\text { Petani/ } \\
\text { nelayan }\end{array}$ & $\begin{array}{l}\text { Pemilik } \\
\text { lahan/ } \\
\text { kapal/pegaw } \\
\text { ai }\end{array}$ \\
\hline
\end{tabular}

\begin{tabular}{|c|c|c|c|c|c|}
\hline & & 30 & 25 & $\underline{20}$ & 15 \\
\hline \multirow[t]{2}{*}{4} & $\begin{array}{l}\text { Ruang gerak } \\
\text { pengunjung } \\
\text { (ha) }\end{array}$ & $>50$ & $41-50$ & $31-40$ & $<30$ \\
\hline & & 30 & 25 & 20 & $\underline{10}$ \\
\hline \multirow[t]{2}{*}{5} & Pendidikan & $\begin{array}{l}\text { Sebagian } \\
\text { besar } \\
\text { lulusan } \\
\text { SLTA ke } \\
\text { atas }\end{array}$ & $\begin{array}{l}\text { Sebagian } \\
\text { besar } \\
\text { lulusan } \\
\text { SLTP }\end{array}$ & $\begin{array}{l}\text { Sebagian } \\
\text { besar } \\
\text { lulusan } \\
\text { SD }\end{array}$ & $\begin{array}{l}\text { Sebagian } \\
\text { besar tidak } \\
\text { lulus SD }\end{array}$ \\
\hline & & 30 & $\underline{25}$ & 20 & 15 \\
\hline \multirow[t]{2}{*}{6} & $\begin{array}{l}\text { Tingkat } \\
\text { kesuburan } \\
\text { tanah }\end{array}$ & $\begin{array}{l}\text { Tidak } \\
\text { subur/ } \\
\text { kritis } \\
\end{array}$ & Sedang & Subur & Sangat subur \\
\hline & & 30 & 25 & $\underline{20}$ & 10 \\
\hline \multirow[t]{2}{*}{$\begin{array}{l}7 \\
.\end{array}$} & $\begin{array}{l}\text { Sumber daya } \\
\text { alam }\end{array}$ & $\begin{array}{l}\text { Tidak } \\
\text { potensial }\end{array}$ & $\begin{array}{l}\text { Kurang } \\
\text { potensial }\end{array}$ & Potensial & $\begin{array}{l}\text { Sangat } \\
\text { potensial }\end{array}$ \\
\hline & & 30 & 25 & $\underline{20}$ & 10 \\
\hline \multirow[t]{2}{*}{$\begin{array}{l}8 \\
.\end{array}$} & $\begin{array}{l}\text { Tanggapan } \\
\text { masyarakat } \\
\text { terhadap } \\
\text { pengembanga } \\
\text { n OWA }\end{array}$ & $\begin{array}{l}\text { Sangat } \\
\text { mendukun } \\
\mathrm{g}\end{array}$ & $\begin{array}{l}\text { Mendukun } \\
\mathrm{g}\end{array}$ & $\begin{array}{l}\text { Cukup } \\
\text { mendukun } \\
\mathrm{g}\end{array}$ & $\begin{array}{l}\text { Kurang } \\
\text { mendukung }\end{array}$ \\
\hline & & $\underline{\mathbf{3 0}}$ & 25 & 20 & 10 \\
\hline \multicolumn{2}{|c|}{ Jumlah Nilai } & 825 & & & \\
\hline
\end{tabular}

Pada tabel 5 dapat diketahui bahwa Sumber Seneng memiliki sedang merencanakan dan pengorganisaikan (20), memiliki penduduk berbahasa Jawa dan Indonesia (15) dan berkomitmen untuk sanggup, siap dan ramah dalam melayani pengunjung (20) sehingga nilai totalnya 220

Tabel 1 Penilaian Pengelolaan dan Pelayanan (Bobot 4)

\begin{tabular}{|c|c|c|c|c|c|}
\hline \multirow{2}{*}{$\begin{array}{l}\text { NO } \\
1 .\end{array}$} & \multirow{2}{*}{$\begin{array}{l}\text { UNSUR/SUB UNSUR } \\
\text { Pengelolaan }\end{array}$} & \multicolumn{4}{|c|}{ NILAI } \\
\hline & & Ada 4 & Ada 3 & Ada 2 & Ada 1 \\
\hline & $\begin{array}{l}\text { a. Perencanaan Obyek } \\
\text { b. Pengorganisasian } \\
\text { c. Pelaksanaan/operasional } \\
\text { d. Pengendalian pemanfaatan }\end{array}$ & 30 & 20 & $\underline{20}$ & 10 \\
\hline \multirow[t]{2}{*}{2.} & Kemampuan berbahasa & Ada 4 & Ada 3 & Ada 2 & Ada 1 \\
\hline & $\begin{array}{l}\text { a. Daerah setempat } \\
\text { b. Indonesia } \\
\text { c. Inggris } \\
\text { d. Asing lainnya }\end{array}$ & 30 & 20 & $\underline{15}$ & 5 \\
\hline \multirow[t]{2}{*}{3} & Pelayanan pengunjung & Ada 4 & Ada 3 & Ada 2 & Ada 1 \\
\hline & $\begin{array}{l}\text { a. Keramahan } \\
\text { b. Kesiapan } \\
\text { c. Kesanggupan } \\
\text { d. Kemampuan komunikasi }\end{array}$ & 30 & $\underline{20}$ & 15 & 5 \\
\hline Jum & Nilai & 220 & & & \\
\hline
\end{tabular}

Pada tabel 6 dapat diketahui bahwa Sumber Seneng memiliki berpotensi untuk dikunjungi sepanjang tahun (30) dengan temperatur sekitar $24^{\prime} \mathrm{C}$ (25) yang kering (30) beserta kelembaban tinggi (30) sehingga nilai totalnya 460

Tabel 2 Penilaian Iklim (Bobot 4)

\begin{tabular}{|c|c|c|c|c|c|c|}
\hline No & UNSUR/SUB UNSUR & & & NIL & & \\
\hline \multirow[t]{3}{*}{1.} & Pengaruh iklim terhadap & $10-12$ & $7-9$ & $4-6$ & $2-3$ & $<2$ bln \\
\hline & lama waktu kunjungan & bln & bln & bln & bln & \\
\hline & & $\underline{30}$ & 25 & 20 & 15 & 10 \\
\hline
\end{tabular}




\begin{tabular}{|c|c|c|c|c|c|c|}
\hline \multirow[t]{2}{*}{2} & $\begin{array}{l}\text { Suhu udara pada musim } \\
\text { kemarau }\left({ }^{0} \mathrm{C}\right)\end{array}$ & $20-21$ & $\begin{array}{l}22- \\
24 / \\
17- \\
19\end{array}$ & $\begin{array}{l}25- \\
27 / \\
14- \\
16\end{array}$ & $\begin{array}{l}28- \\
30 / \\
11- \\
13\end{array}$ & $\begin{array}{l}>30 \\
<10\end{array}$ \\
\hline & & 30 & $\underline{25}$ & 20 & 15 & 10 \\
\hline \multirow[t]{2}{*}{3} & $\begin{array}{l}\text { Jumlah bulan kering } \\
\text { rata-rata per tahun }\end{array}$ & 8 bln & 7 bln & 6 bln & 5 bln & 4 bln \\
\hline & & $\underline{\text { 30 }}$ & 20 & 15 & 10 & 5 \\
\hline \multirow[t]{2}{*}{4} & $\begin{array}{l}\text { Kelembaban rata-rata } \\
\text { per tahun }\end{array}$ & $>65 \%$ & $\begin{array}{l}60- \\
65 \%\end{array}$ & $\begin{array}{l}59- \\
55 \%\end{array}$ & $\begin{array}{l}54- \\
45 \%\end{array}$ & $<45 \%$ \\
\hline & & $\underline{\text { 30 }}$ & 20 & 15 & 10 & 5 \\
\hline \multicolumn{2}{|c|}{ Jumlah Nilai } & 460 & & & & \\
\hline
\end{tabular}

Pada tabel 7 dapat diketahui bahwa Sumber Seneng hanya memiliki penginapan pada radius $15 \mathrm{~km}$ dengan kamar kurang dari 30 sehingga hanya mendapat nilai 30

Tabel 3 Penilaian Akomodasi (Bobot 3)

\begin{tabular}{lllllll}
\hline NO & UNSUR/SUB UNSUR & \multicolumn{5}{c}{ NILAI } \\
\hline 1. & Jumlah kamar (buah) & $>100$ & ${ }^{75-100}$ & $50-75$ & $30-50$ & s/d 30 \\
\hline & 30 & 25 & 20 & 15 & $\underline{\mathbf{1 0}}$ \\
\hline Jumlah Nilai & $\mathbf{3 0}$ & & & & \\
\hline
\end{tabular}

Keterangan: Akomodasi dalam radius $15 \mathrm{~km}$ dari obyek

Pada tabel 8 dapat diketahui bahwa Sumber Seneng hanya memiliki penginapan dan warung (20), jalan dan listrik (20) hanya mendapat nilai 120

Tabel 4 Penilaian Sarana dan Prasarana Penunjang (Bobot 3)

\begin{tabular}{|c|c|c|c|c|c|c|}
\hline NO & UNSUR/SUB UNSUR & & & NIL & & \\
\hline \multirow[t]{2}{*}{1.} & Sarana & $\begin{array}{l}>4 \\
\text { tipe }\end{array}$ & $\begin{array}{l}3 \\
\text { tipe }\end{array}$ & $\begin{array}{l}2 \\
\text { tipe }\end{array}$ & $\begin{array}{l}1 \\
\text { tipe }\end{array}$ & $\begin{array}{l}\text { Tidak } \\
\text { ada }\end{array}$ \\
\hline & $\begin{array}{l}\text { a. Akomodasi } \\
\text { b. Rumah } \\
\text { makan/minum } \\
\text { c. Sarana wisata tirta } \\
\text { d. Sarana wisata } \\
\text { budaya } \\
\text { e. Sarana angkutan } \\
\text { umum } \\
\text { f. Kios cenderamata }\end{array}$ & 30 & 25 & $\underline{\mathbf{2 0}}$ & 15 & 10 \\
\hline \multirow[t]{2}{*}{2.} & Prasarana & $\begin{array}{l}>4 \\
\text { tipe }\end{array}$ & $\begin{array}{l}3 \\
\text { tipe }\end{array}$ & $\begin{array}{l}2 \\
\text { tipe }\end{array}$ & $\begin{array}{l}1 \\
\text { tipe }\end{array}$ & $\begin{array}{l}\text { Tidak } \\
\text { ada }\end{array}$ \\
\hline & $\begin{array}{l}\text { a. Jalan } \\
\text { b. Jembatan } \\
\text { c. Areal parkir } \\
\text { d. Jaringan listrik } \\
\text { e. Jaringan air minum } \\
\text { f. Jaringan telepon } \\
\text { g. Jaringan drainase/ } \\
\text { saluran } \\
\text { h. Sistem pembuangan } \\
\text { limbah } \\
\text { i. Dermaga / pelabuhan } \\
\text { j. Helipad }\end{array}$ & 30 & 25 & $\underline{20}$ & 15 & 5 \\
\hline \multicolumn{2}{|c|}{ Jumlah NIlai } & 120 & & & & \\
\hline
\end{tabular}

Pada tabel 9 dapat diketahui bahwa Sumber Seneng melimpah dalam hal sumber daya air bersih, tetapi masih belum diolah (lihat gambar 4). Sehingga untuk kategori ini mendapat angka optimum 840 .

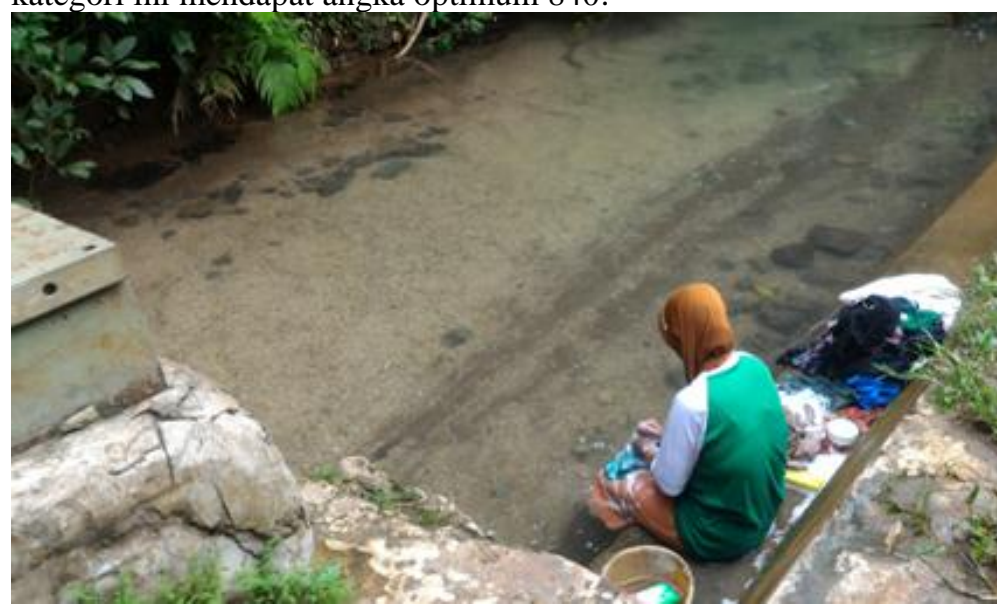

Gambar 4. Kondisi pemandian dan sumber air pada kawasan wisata alam

Tabel 5 Penilaian Ketersediaan Air Bersih (Bobot 6)

\begin{tabular}{|c|c|c|c|c|c|}
\hline NO & $\begin{array}{l}\text { UNSUR/SUB } \\
\text { UNSUR }\end{array}$ & NILAI & & & \\
\hline \multirow[t]{2}{*}{1 . } & Volume & Banyak & $\begin{array}{l}\text { Cukup } \\
\text { banyak }\end{array}$ & Sedikit & $\begin{array}{l}\text { Sangat } \\
\text { sedikit }\end{array}$ \\
\hline & & $\underline{\text { 30 }}$ & 20 & 20 & 5 \\
\hline \multirow[t]{2}{*}{2} & $\begin{array}{l}\text { Jarak lokasi air } \\
\text { bersih terhadap } \\
\text { lokasi obyek }\end{array}$ & $0-1 \mathrm{~km}$ & $1,1-2 \mathrm{~km}$ & $2,1-4 \mathrm{~km}$ & $>4 \mathrm{~km}$ \\
\hline & & $\underline{\text { 30 }}$ & 20 & 20 & 10 \\
\hline \multirow[t]{2}{*}{3} & $\begin{array}{l}\text { Dapat tidaknya } \\
\text { air dialirkan ke } \\
\text { obyek }\end{array}$ & $\begin{array}{l}\text { Sangat } \\
\text { mudah }\end{array}$ & Mudah & $\begin{array}{l}\text { Agak } \\
\text { Sukar }\end{array}$ & Sukar \\
\hline & & $\underline{\underline{\mathbf{3 0}}}$ & 20 & 20 & 15 \\
\hline \multirow[t]{2}{*}{4} & $\begin{array}{l}\text { Kelayakan } \\
\text { dikonsumsi }\end{array}$ & $\begin{array}{l}\text { Dapat } \\
\text { langsung } \\
\text { dikonsumsi }\end{array}$ & $\begin{array}{l}\text { Perlu } \\
\text { perlakuan } \\
\text { sederhana }\end{array}$ & $\begin{array}{l}\text { Perlakuan } \\
\text { dengan } \\
\text { bahan } \\
\text { kimia } \\
\end{array}$ & $\begin{array}{l}\text { Tidak } \\
\text { layak }\end{array}$ \\
\hline & & 30 & $\underline{20}$ & 15 & 5 \\
\hline \multirow[t]{2}{*}{5} & Ketersediaan & $\begin{array}{l}\text { Sepanjang } \\
\text { tahun }\end{array}$ & 6-9 bulan & $3-6$ bulan & $\begin{array}{l}<3 \\
\text { bulan }\end{array}$ \\
\hline & & $\underline{30}$ & 20 & 20 & 10 \\
\hline \multicolumn{2}{|c|}{ Jumlah Nilai } & 840 & & & \\
\hline
\end{tabular}

Pada tabel 10 menjelaskan bahwa Sumber Seneng masih minim objek wisata bahkan hingga $200 \mathrm{~km}$ keluar area sehingga mendapat poin 60 saja. Kawasan TWA Sumber Semen mempunyai potensi wisata situs budaya “ Mbah Dander" yang berada di sekitar kawasan tersebut. Hal ini menambah daya tarik wisata alam dan dapat dikembangkan menjadi kawasan yang terintegrasi (lihat gambar 5). 


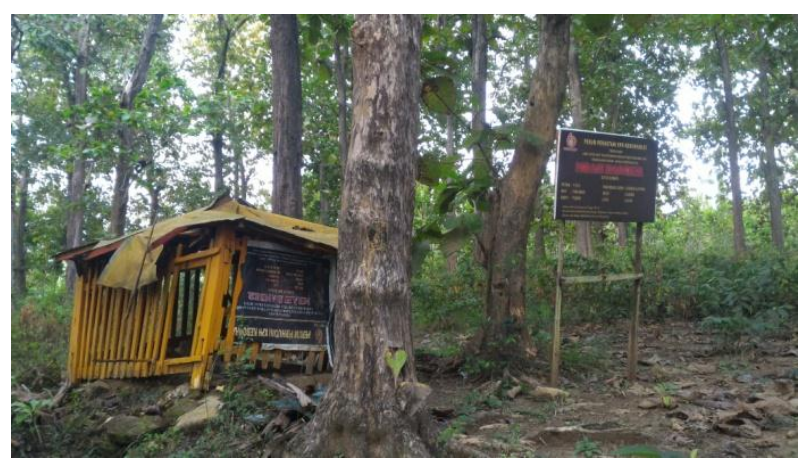

Gambar 5. Situs budaya 'Mbah Dander" yang berada di sekitar kawasan.

Tabel 6 Penilaian Hubungan dengan Obyek Wisata di Sekitarnya (Bobot 1)

\begin{tabular}{|c|c|c|c|c|c|c|c|c|c|c|}
\hline \multirow{3}{*}{ No } & \multirow{3}{*}{$\begin{array}{l}\text { Jarak } \\
(\mathbf{K m})\end{array}$} & \multirow{3}{*}{$\begin{array}{l}\text { Obyek } \\
\text { Wisata }\end{array}$} & \multicolumn{7}{|c|}{ Jumlah Obyek Wisata } & \multirow{3}{*}{ Jumlah } \\
\hline & & & $\mathbf{0}$ & 1 & 2 & 3 & 4 & 5 & 6 & \\
\hline & & & \multicolumn{7}{|c|}{ NILAI } & \\
\hline \multirow[t]{2}{*}{1.} & s/d 50 & Sejenis & 100 & 80 & 60 & 40 & 20 & 1 & - & \multirow{8}{*}{60} \\
\hline & & $\begin{array}{l}\text { Tak } \\
\text { Sejenis }\end{array}$ & 100 & 95 & 90 & 80 & 70 & $\underline{60}$ & 50 & \\
\hline \multirow[t]{2}{*}{2} & $\begin{array}{l}51- \\
100\end{array}$ & Sejenis & 80 & 100 & 80 & 60 & 40 & 20 & 1 & \\
\hline & & $\begin{array}{l}\text { Tak } \\
\text { Sejenis }\end{array}$ & 70 & 80 & 90 & 100 & 90 & 80 & 70 & \\
\hline \multirow[t]{2}{*}{3} & $\begin{array}{l}101- \\
150\end{array}$ & Sejenis & 60 & 80 & 100 & 80 & 60 & 40 & 20 & \\
\hline & & $\begin{array}{l}\text { Tak } \\
\text { Sejenis }\end{array}$ & 50 & 60 & 70 & 80 & 90 & 100 & 90 & \\
\hline \multirow[t]{2}{*}{4} & $\begin{array}{l}151- \\
200\end{array}$ & Sejenis & 40 & 60 & 80 & 100 & 80 & 60 & 40 & \\
\hline & & $\begin{array}{l}\text { Tak } \\
\text { Sejenis }\end{array}$ & 30 & 40 & 50 & 60 & 70 & 80 & 90 & \\
\hline
\end{tabular}

Pada tabel 11 menjelaskan bahwa Sumber Seneng sangat aman alamnya tetapi berpotensi rawan terhadap perambahan hutan sehingga total nilai hanya 525

Tabel 7 Penilaian Keamanan (Bobot 5)

\begin{tabular}{|c|c|c|c|c|c|}
\hline $\begin{array}{l}\mathbf{N} \\
\mathbf{O}\end{array}$ & $\begin{array}{l}\text { UNSUR/SU } \\
\text { B UNSUR }\end{array}$ & NILAI & & & \\
\hline \multirow[t]{2}{*}{1.} & $\begin{array}{l}\text { Keamanan } \\
\text { pengunjung }\end{array}$ & Ada 4 & Ada 3 & Ada 2 & Ada 1 \\
\hline & $\begin{array}{l}\text { a. Tidak ada } \\
\text { binatang } \\
\text { pengganggu } \\
\text { b. Tidak ada } \\
\text { situs } \\
\text { berbahaya } \\
\text { dan tanah } \\
\text { labil } \\
\text { c. Jarang } \\
\text { gangguan } \\
\text { Kamtibmas } \\
\text { d. Bebas } \\
\text { kepercayaan } \\
\text { (menggangg } \\
\text { u) }\end{array}$ & $\underline{30}$ & 20 & 20 & 15 \\
\hline 2. & $\begin{array}{l}\text { Kebakaran } \\
\text { (berdasarka }\end{array}$ & Alam & $\begin{array}{l}\text { Tidak } \\
\text { disengaja }\end{array}$ & Disengaja & Lain-lain \\
\hline
\end{tabular}

\begin{tabular}{llllll}
\hline & n penyebab) & & & & \\
\hline & & $\underline{30}$ & 20 & 20 & 15 \\
\hline 3. & $\begin{array}{l}\text { Penebangan } \\
\text { liar (untuk } \\
\text { keperluan) }\end{array}$ & Sendiri & $\begin{array}{l}\text { Kepentin } \\
\text { gan } \\
\text { umum }\end{array}$ & $\begin{array}{l}\text { Diperjualbeli } \\
\text { kan }\end{array}$ & $\begin{array}{l}\text { Perdagan } \\
\text { gan besar } \\
\text { liar }\end{array}$ \\
\hline & & $\underline{\mathbf{3 0}}$ & 20 & 20 & 15 \\
\hline 4. & $\begin{array}{l}\text { Perambahan } \\
\text { (pengunaan } \\
\text { lahan) }\end{array}$ & $\begin{array}{l}\text { ladang } \\
\text { berpind } \\
\text { ah }\end{array}$ & $\begin{array}{l}\text { ladangan } \\
\text { menetap }\end{array}$ & Perkebunan & $\begin{array}{l}\text { Permuki } \\
\text { man }\end{array}$ \\
\hline & 30 & 20 & 20 & $\underline{\mathbf{5 5}}$ \\
\hline Jumlah Nilai & $\mathbf{5 2 5}$ & & & \\
\hline
\end{tabular}

Pada tabel 12 menjelaskan bahwa Sumber Seneng memiliki daya dukung lahan alam yang tinggi tetapi kurang dimanfaatkan selain untuk perambahan hutan sehingga total nilai hanya 405

Tabel 8 Penilaian Daya Dukung Kawasan (Bobot 3)

\begin{tabular}{|c|c|c|c|c|c|}
\hline NO & $\begin{array}{l}\text { UNSUR/SUB } \\
\text { UNSUR }\end{array}$ & NILAI & & & \\
\hline \multirow[t]{2}{*}{1.} & $\begin{array}{l}\text { Jumlah } \\
\text { pengunjung } \\
\text { (orang/hari/ha) }\end{array}$ & $<100$ & $100-150$ & $150-200$ & $>200$ \\
\hline & & $\underline{\text { 30 }}$ & 25 & 15 & 5 \\
\hline \multirow[t]{2}{*}{2.} & $\begin{array}{l}\text { Kepekaan } \\
\text { tanah terhadap } \\
\text { erosi }\end{array}$ & $\begin{array}{l}\text { Tidak } \\
\text { peka }\end{array}$ & $\begin{array}{l}\text { Kurang } \\
\text { peka }\end{array}$ & Peka & $\begin{array}{l}\text { Sangat } \\
\text { peka }\end{array}$ \\
\hline & & $\underline{\mathbf{3 0}}$ & 25 & 15 & 5 \\
\hline \multirow[t]{2}{*}{3.} & $\begin{array}{l}\text { Kemiringan } \\
\text { lahan }(\%)\end{array}$ & $0-8$ & 8-15 & $15-25$ & $>25$ \\
\hline & & $\underline{\mathbf{3 0}}$ & 25 & 15 & $\underline{\mathbf{5}}$ \\
\hline \multirow[t]{2}{*}{4.} & Jenis kegiatan & Penelitian & $\begin{array}{l}\text { Rekreasi } \\
\text { alam }\end{array}$ & Berkemah & $\begin{array}{l}\text { Mendaki } \\
\text { gunung }\end{array}$ \\
\hline & & $\underline{\mathbf{3 0}}$ & 25 & 15 & 5 \\
\hline \multirow[t]{2}{*}{5.} & $\begin{array}{l}\text { Luas unit zona } \\
\text { pemanfaatam } \\
\text { (ha) }\end{array}$ & $>150$ & $100-150$ & $50-100$ & $<50$ \\
\hline & & 30 & 25 & 20 & $\underline{15}$ \\
\hline \multicolumn{2}{|c|}{ Jumlah NIlai } & 405 & & & \\
\hline
\end{tabular}

Pada tabel 13,14,15 menjelaskan bahwa Sumber Seneng masih belum tertata rapi dan dipersiapkan untuk menjadi objek wisata yang potensial bagi wisatawan luar negeri maupun pengusaha, meskipun tarif wisatanya sangat rendah.

Tabel 9 Penilaian Pengaturan Pengunjung (Bobot 3)

\begin{tabular}{lllllll}
\hline No & UNSUR/SUB UNSUR & NILAI & & & \\
\hline 1. & Kenyamanan & $\begin{array}{l}\text { Ada } \\
\mathbf{5}\end{array}$ & $\begin{array}{l}\text { Ada } \\
\mathbf{4}\end{array}$ & $\begin{array}{l}\text { Ada } \\
\mathbf{3}\end{array}$ & $\begin{array}{l}\text { Ada } \\
\mathbf{2}\end{array}$ & $\begin{array}{l}\text { Ada } \\
\mathbf{1}\end{array}$ \\
\hline $\begin{array}{l}\text { a. Pembatasan pengunjung } \\
\text { b. Distribusi pengunjung } \\
\begin{array}{l}\text { c. Pemusatan kegiatan } \\
\text { pengunjung }\end{array}\end{array}$ & 30 & 25 & 20 & $\underline{\mathbf{1 5}}$ & 10 \\
$\quad \begin{array}{l}\text { d. Lama tinggal kunjungan } \\
\text { e. Musim kunjungan }\end{array}$ & & & & & & \\
\hline Jumlah Nilai & $\mathbf{4 5}$ & & & & & \\
\hline
\end{tabular}


Tabel 10 Penilaian Pemasaran (Bobot 4)

\begin{tabular}{|c|c|c|c|c|c|}
\hline $\mathrm{NO}$ & UNSUR/SUB UNSUR & NILAI & & & \\
\hline \multirow[t]{2}{*}{1.} & Bauran pemasaran & $\begin{array}{l}\text { Ada } \\
4\end{array}$ & $\begin{array}{l}\text { Ada } \\
3\end{array}$ & $\begin{array}{l}\text { Ada } \\
2\end{array}$ & $\begin{array}{l}\text { Ada } \\
1\end{array}$ \\
\hline & $\begin{array}{l}\text { a. Tarif/harga terjangkau } \\
\text { b. Produk wisata (ODTWA) } \\
\text { bervariasi } \\
\text { c. Sarana penyampaian informasi } \\
\text { d. Promosi }\end{array}$ & 30 & 25 & $\underline{15}$ & 5 \\
\hline Jum & Nilai & 60 & & & \\
\hline
\end{tabular}

Tabel 11 Penilaian Pangsa Pasar (Bobot 3)

\begin{tabular}{|c|c|c|c|c|c|}
\hline N & $\begin{array}{l}\text { UNSUR } \\
\text { /SUB }\end{array}$ & \multicolumn{4}{|c|}{ NILAI } \\
\hline \multirow[t]{2}{*}{1.} & $\begin{array}{l}\text { Asal } \\
\text { pengunju } \\
\text { ng }\end{array}$ & Wisman & $\begin{array}{l}\text { Wisnus } \\
\text { (luar } \\
\text { kabupaten } \\
\text { ) }\end{array}$ & $\begin{array}{l}\text { Wisnus } \\
\text { (dalam } \\
\text { kabupaten) }\end{array}$ & $\begin{array}{l}\text { Wisnus } \\
\text { (masyara } \\
\text { kat lokal) }\end{array}$ \\
\hline & & 30 & $\underline{25}$ & 20 & 15 \\
\hline \multirow[t]{2}{*}{2.} & $\begin{array}{l}\text { Tingkat } \\
\text { pendidika } \\
\text { n } \\
\end{array}$ & $\begin{array}{l}\text { Pergurua } \\
\text { n Tinggi }\end{array}$ & SLTA & SLTP & SD \\
\hline & & 30 & $\underline{25}$ & 15 & 5 \\
\hline \multirow[t]{2}{*}{3.} & $\begin{array}{l}\text { Mata } \\
\text { pencahari } \\
\text { an }\end{array}$ & $\begin{array}{l}\text { Pengusah } \\
\text { a } \\
\text { (wiraswas } \\
\text { ta) }\end{array}$ & $\begin{array}{l}\text { Pegawai } \\
\text { swasta/neg } \\
\text { eri }\end{array}$ & $\begin{array}{l}\text { Petani/nelay } \\
\text { an }\end{array}$ & Buruh \\
\hline & & 30 & $\underline{25}$ & 20 & 15 \\
\hline & h Nilai & 225 & & & \\
\hline
\end{tabular}

Penghitungan dari ke 15 penilaian kuantitatif didapatkan total Nilai $=\mathrm{I}+\mathrm{II}+\mathrm{III}+\mathrm{IV}+\mathrm{V}+\mathrm{VI}+\mathrm{VII}+\mathrm{VIII}+$ $\mathrm{IX}+\mathrm{X}+\mathrm{XI}+\mathrm{XII}+\mathrm{XIII}+\mathrm{XIV}+\mathrm{XV}=$ $1230+825+550+825+220+460+30+120+840+60+525+4$ $05+45+60+225=6.420$

Hasil penilaian terhadap unsur dan sub unsur tiap-tiap kriteria ODTWA di kawasan TWA Sumber Semen kemudian diklasifikasikan tingkat kelayakannya untuk pengembangan potensi ODTWA. Pengklasifikasian tingkat kelayakan potensi ODTWA di kawasan Sumber Seneng menggunakan perhitungan:

1. Rendah , 2. Sedang, 3. Tinggi yang didapat dari nilai maksimal dan nilai minimal kriteria penilaian ODTWA (tabel 16) sehingga dapat dihasilkan bahwa Sumber seneng memiliki potensi yang tinggi $(81,86)$ untuk dikembangkan menjadi daerah wisata (lihat tabel 17)

Tabel 16. Klasifikasi Nilai Minimal dan Maksimal

\section{ODTWA}

\begin{tabular}{lllll}
\hline No & Kriteria Penilaian & Minimal & Maksimal & Interval \\
\hline 1 & $\begin{array}{l}\text { Daya tarik ODTWA berbentuk } \\
\text { darat }\end{array}$ & 480 & 1440 & 320 \\
\hline 2 & Potensi pasar & 230 & 950 & 240 \\
\hline 3 & Kadar hubungan / aksesibilitas & 105 & 900 & 265 \\
\hline 4 & Kondisi sekitar kawasan & 450 & 1200 & 250 \\
\hline 5 & Pengelolaan dan pelayanan & 80 & 360 & 93,33 \\
\hline 6 & Iklim & 120 & 480 & 120 \\
\hline 7 & Akomodasi & 30 & 90 & 20 \\
\hline 8 & Sarana dan prasarana penunjang & 45 & 180 & 45 \\
\hline 9 & Ketersediaan air bersih & 270 & 900 & 210 \\
\hline
\end{tabular}

\begin{tabular}{|c|c|c|c|c|}
\hline 10 & $\begin{array}{l}\text { Hubungan dengan obyek wisata } \\
\text { di sekitarnya }\end{array}$ & 0 & 100 & 33,33 \\
\hline 11 & Keamanan & 250 & 600 & 116,67 \\
\hline 12 & Daya dukung kawasan & 90 & 450 & 120 \\
\hline 13 & Pengaturan pengunjung & 30 & 90 & 20 \\
\hline 14 & Pemasaran & 20 & 120 & 33,33 \\
\hline \multirow[t]{2}{*}{15} & Pangsa pasar & 105 & 270 & 55 \\
\hline & & 2305 & 8130 & 1941,67 \\
\hline No & Kriteria Penilaian & Rendah & Sedang & Tinggi \\
\hline 1 & $\begin{array}{lcc}\begin{array}{l}\text { Daya tarik } \\
\text { berbentuk darat }\end{array} & \text { ODTWA } \\
\end{array}$ & $480-800$ & $801-1120$ & $1121-1440$ \\
\hline 2 & Potensi pasar & $230-470$ & $471-710$ & $711-950$ \\
\hline 3 & $\begin{array}{ll}\text { Kadar } & \text { hubungan/ } \\
\text { aksesibilitas } & \\
\end{array}$ & $105-370$ & $371-635$ & $636-900$ \\
\hline 4 & Kondisi sekitar kawasan & $450-700$ & $701-950$ & $951-1200$ \\
\hline 5 & Pengelolaan dan pelayanan & $80-173,33$ & $\begin{array}{l}173,34- \\
266,67\end{array}$ & $\begin{array}{l}266,68- \\
360\end{array}$ \\
\hline 6 & Iklim & $120-240$ & $241-360$ & $361-480$ \\
\hline 7 & Akomodasi & $30-50$ & $51-70$ & $71-90$ \\
\hline 8 & $\begin{array}{l}\text { Sarana dan prasarana } \\
\text { penunjang }\end{array}$ & $45-90$ & $91-135$ & $136-180$ \\
\hline 9 & Ketersediaan air bersih & $270-480$ & $481-690$ & $691-900$ \\
\hline 10 & $\begin{array}{l}\text { Hubungan dengan obyek } \\
\text { wisata di sekitarnya }\end{array}$ & $0-33,33$ & $33,34-66,67$ & $66,68-100$ \\
\hline 11 & Keamanan & $\begin{array}{l}250- \\
366,67\end{array}$ & $\begin{array}{l}366,68- \\
483,33\end{array}$ & $\begin{array}{l}483,34- \\
600\end{array}$ \\
\hline 12 & Daya dukung kawasan & $90-210$ & $211-330$ & $331-450$ \\
\hline 13 & Pengaturan pengunjung & $30-50$ & $51-70$ & $71-90$ \\
\hline 14 & Pemasaran & $20-53,33$ & $53,34-86,67$ & $86,68-120$ \\
\hline 15 & Pangsa pasar & $105-160$ & $161-215$ & $216-270$ \\
\hline & Jumlah & $\begin{array}{l}2305- \\
4246,67\end{array}$ & $\begin{array}{l}4246,68- \\
6188,33\end{array}$ & $\begin{array}{l}\text { 6188,34- } \\
8130\end{array}$ \\
\hline
\end{tabular}

Tabel 17. Nilai ODTWA Sumber Seneng

\begin{tabular}{|c|c|c|c|c|}
\hline Kriteria & $\begin{array}{l}\text { Nilai } \\
\text { Maksimal } \\
\text { Potensi } \\
\text { ODTWA }\end{array}$ & $\begin{array}{l}\text { Nilai } \\
\text { Potensi } \\
\text { ODTWA }\end{array}$ & $\begin{array}{l}\text { Indeks } \\
\text { Nilai } \\
\text { Potensi } \\
(\%)\end{array}$ & $\begin{array}{l}\text { Klasifikasi } \\
\text { Potensi } \\
\text { ODTWA }\end{array}$ \\
\hline $\begin{array}{lr}\text { Daya } & \text { tarik } \\
\text { obyek } & \text { wisata } \\
\text { darat } & \\
\end{array}$ & 1440 & 1230 & 85,42 & Tinggi \\
\hline Potensi pasar & 950 & 825 & 86,84 & Tinggi \\
\hline $\begin{array}{l}\text { Kadar } \\
\text { hubungan/ } \\
\text { Aksesibilitas }\end{array}$ & 900 & 550 & 61,11 & Sedang \\
\hline $\begin{array}{ll}\text { Kondisi } & \text { sekitar } \\
\text { kawasan } & \\
\end{array}$ & 1200 & 825 & 68,75 & Sedang \\
\hline $\begin{array}{l}\text { Pengelolaan dan } \\
\text { pelayanan }\end{array}$ & 360 & 220 & 61,11 & Sedang \\
\hline Iklim & 480 & 460 & 95,83 & Tinggi \\
\hline Akomodasi & 90 & 30 & 33,33 & Rendah \\
\hline $\begin{array}{ll}\text { Sarana } & \text { dan } \\
\text { prasarana } & \\
\text { penunjang } & \\
\end{array}$ & 180 & 120 & 66,67 & Sedang \\
\hline $\begin{array}{l}\text { Ketersediaan air } \\
\text { bersih }\end{array}$ & 900 & 840 & 93,33 & Tinggi \\
\hline \begin{tabular}{lr}
\multicolumn{2}{l}{ Hubungan } \\
dengan & obyek \\
wisata & di \\
sekitarnya &
\end{tabular} & 100 & 60 & 60 & Sedang \\
\hline Keamanan & 600 & 525 & 87,50 & Tinggi \\
\hline $\begin{array}{l}\text { Daya dukung } \\
\text { kawasan }\end{array}$ & 450 & 405 & 90 & Tinggi \\
\hline $\begin{array}{l}\text { Pengaturan } \\
\text { pengunjung }\end{array}$ & 90 & 45 & 50 & Sedang \\
\hline
\end{tabular}




\begin{tabular}{lllll}
\hline Pemasaran & 120 & 60 & 50 & Sedang \\
\hline Pangsa Pasar & 270 & 225 & 83,33 & Tinggi \\
\hline HASIL AKHIR & $\mathbf{8 . 1 3 0}$ & $\mathbf{6 . 4 2 0}$ & $\mathbf{8 1 , 8 6}$ & Tinggi \\
\hline
\end{tabular}

\section{KESIMPULAN DAN REKOMENDASI}

Berdasarkan hasil kajian yang telah dilakukan terdapat beberapa hal yang harus dilakukan yaitu untuk merealisasikan pengembangan wisata ini diharapkan melakukan koordinasi kepada berbagai pihak yang berkepentingan, khususnya dalam penyediaan fasilitas serta sarana untuk pengembangan kawasan wisata, seperti sarana akomodasi, transportasi dan sarana penunjang lainnya serta lahan yang akan dipakai. Sumber pembiayaan pembangunan dapat diperoleh dari 3 sumber dasar, yaitu dari pemerintah/ publik, swasta/private serta gabungan antara pemerintah dengan swasta.

Khusus untuk Kawasan TWA Sumber Semen perlu ditingkatkan lagi pembangunan dan pengembangan sarana akomodasi. Dalam analisis hasil penilaian menunjukkan skor yang rendah, dalam arti fasilitas akomodasi sangat minim di area tersebut dalam jarak 1,5 kilometer. Pengembangan sarana akomodasi dapat melibatkan pihak ketiga, meliputi masyarakat setempat dengan membangun homestay atau pihak swasta dengan membangun hotel/ penginapan. Dikarenakan area Kawasan TWA Sumber Semen merupakan tempat wisata yang potensial dengan menunjukkan hasil skor yang tinggi serta pangsa pasar yang tinggi mempunyai arti tempat wisata tersebut diminati masyarakat.

\section{DAFTAR PUSTAKA}

Direktorat Produk Pariwisata (2003) Pedoman Penilaian Daya Tarik Wisata. Direktorat Jenderal Pengembangan Destinasi Wisata. Departemen Kebudayaan dan Pari-wisata Republik Indonesia

Jainuri, Sudirman Muin, Reine Suci Wulandari (2014) Assessment of Pull Factor and Development of Tanjung Belandang Beach at Ketapang Regency, Jurnal Hutan Lestari vol 2 no 2 p 207-219

Sigit Purwanto, Lailan Syaufina, Andi Gunawan (2014) Study of Potential and Carrying Capacity of Bukit Kelam Natural Tourism Park for Ecotourism Development Strategy, Jurnal Pengelolaan Sumberdaya Alam dan Lingkungan Vol. 4 No. 2, p 119-125

Perlindungan Hutan dan KonservasiAlam (PHKA) (2003). Pedoman Analisis Daerah Operasi Obyek dan Daya Tarik Wisata Alam (ADO-ODTWA) Direktorat Jenderal Perlindungan Hutan dan Konservasi Alam. Bogor 